\title{
Subterranean Foraging and Burrowing Activity of the Common Shrew
}

\author{
Sara CHURCHFIELD ${ }^{1}$
}

Churchfield S., 1980: Subterranean foraging and burrowing activity of the common shrew. Acta theriol, 25, 37: 451-459 [With 2 Figs.].

Common shrews, Sorex araneus Linnaeus, 1758, were maintained in outdoor enclosures provided with soil and leaf litter and investigations made of their ability to locate pupae buried at different depths and densities in the soil. Information was collected on the burrowing activity of shrews. The methods of prey location and the use of subterranean tunnels by shrews are discussed.

[Dept. Zool., Westfield College, Kidderpore Avenue, London NW3 7ST, England].

\section{INTRODUCTION}

The diet of Sorex araneus in the wild has been the subject of several studies, for example Mezhzherin (1958), Kisielewska (1963), Rudge (1968), Pernetta (1976) and Churchfield (1979). It has been found to consist not only of invertebrates active on the ground surface, such as staphylinid beetles and araneids, but also a substantial number which are either strictly soil dwelling, such as many lumbricids, or remain in the soil for part of their life cycle, such as tipulid larvae and pupae. However, little is known of the foraging strategy of shrews, in particular the location of prey beneath the ground surface.

Pernetta $(1973,1977)$ found that prey detection on the ground surface was aided by auditory and tactile stimuli but these stimuli, together with sight, are of limited use when prey is hidden or lies quiescent in the soil. Holling $(1958,1959)$ found that the American shrews Sorex cinereus cinereus (Kerr, 1792) and Blarina brevicauda talpoides (Gapper, 1830) were able to find prey hidden in shallow sand and suggested that scent is important in prey location, but whether S. araneus shows a similar ability to find prey hidden in the soil is not known.

1 Present address: Dept. Zool., Chelsea College, Hortensia Road, London SW1O, England. 
Likewise, little is known of the burrowing ability of shrews in the wild, although they are thought to use subterranean tunnels. Bcth A d ams (1912) and Crowcroft (1955) found $S$. araneus to be an active burrower in captivity and $\mathrm{H}$ a milt o $\mathrm{n}(1931)$ reports that Blarina brevicauda (Say, 1823) is able to construct subterranean tunnels, but there is no information on the extent of burrows created by $S$. araneus under natural conditions.

This paper presents an investigation of the sub-surface foraging ability of $S$. araneus and its burrowing activity under semi-natural conditions in outdoor enclosures.

\section{METHODS}

\subsection{Maintenance of Shrews in the Experimental Enclosures}

Shrews were maintained in outdoor enclosures, each measuring $1.22 \mathrm{~m}$ by $0.8 \mathrm{~m}$ in size, with walls of rigid P.V.C. $0.7 \mathrm{~m}$ high and lids of wire mesh. The enclosures were provided with $300 \mathrm{~mm}$ depth of garden soil, on top of a wre mesh base to contain the shrews. On the surface of the soil a covering of leaf litter was placed.

Shrews were placed individually in the enclosures and were provided wth a nest-box containing hay and an abundant supply of food and water at ose end of the enclosure. This wliving area « was left undisturbed for the duratim? of the experiments. To encourage the shrews to search for food buried in the soil and to aid their survival if they failed to locate prey, minced beef was provided as an additional food source: shrews would eat this but they showed a preference for the experimental food of blowfly (Calliphora sp.) pupae. Eah shrew was kept in the same enclosure for the duration of the experiments ald was allowed at least one week to habituate to its surroundings before expeiments commenced.

All the shrews used were juveniles or sub-adults, and experiments wee conducted in the summer and autumn of 1977 when warm dry conditions prvailed.

\subsection{Organisation of the Food Points}

The food points were located using a grid divided into $50 \mathrm{~mm}$ by $50 \mathrm{mn}$ squares, each square with its own coordinates, which was placed on the grourd surface inside the enclosures, and through which marker sticks were pushed ino the soil. The coordinates of the food points were determined from a set if random numbers, a different set of numbers being used for each experiment.

At each food point a metal corer of $25 \mathrm{~mm}$ diameter was used to remove a plug of soil to the required depth and blowfly pupae (which had been kept cod to prevent emergence of adults) were placed in the hole. The hole was the filled with soil and the marker stick removed. When all the food points had been set up the ground surface was gently compressed, raked over and the lef litter redistributed to prevent identification of the disturbed areas by shrew. 
The enclosures were left undisturbed for two days to encourage the shrews to forage, after which the food points were again identified using the grid and marker sticks. A plug of soil was removed from each point using a corer of $75 \mathrm{~mm}$ diameter to allow for any accidental displacement of the pupae. The pupae were searched for in the soil plug and the numbers recovered were recorded. Results were expressed in terms of percentage predation of pupae, which referred to the percentage of the total number of buried pupae which had been taken by shrews.

\subsection{Control Experiments}

To tesit the efficiency of the experimental design, particularly the recovery techniquie, pupae were buried in groups of five and singly at 10 points at depths of $20-120 \mathrm{~mm}$ and recovered after two days, before the shrews were placed in the enclosures. To check that pupae did not emerge into adults, some were observed in jars during each experimental period.

\subsection{Predation at Different Soil Depths}

Pupae were placed at soil depths of $20-160 \mathrm{~mm}$ to investigate the ability of shrew/s to locate hidden, inactive prey. Only 10 food points were provided to insure that their proximity to each other was not the reason fer their detection. Initially, groups of live pupae were used to facilitate the recovery of untaten prey, but subsequent experiments showed that survival and recovery of single pupae was possible and further trials were conducted using single prey itens. No pupae were placed on the ground surface because of the possibility of ther accidental displacement rather than their predation. A minimum of three trials, using different shrews, were conducted at each depth.

\subsection{Predation at Different Prey Densities}

Fupae were placed singly at between one and 40 food points. A depth of $5 \mathrm{~mm}$ was used because all shrews were able to locate prey at this depth and it minimised the possibility of pupae being displaced by the normal exploratory morements of shrews. A minimum of three trials, using different shrews, were conducted at each density.

\subsection{Burrowing Activity}

Ifformation on the burrowing activity of shrews in the enclosures was collected both dluring and after the foraging experiments.

\section{RESULTS}

\subsection{Control Experiments}

Pupae buried in the absence of shrews showed $100 \%$ recovery after tw days. Pupae kept in jars did not emerge into adults within the two-day trial period, although some did emerge after 5 days. 


\subsection{Predation at Different Soil Depths}

The mean percentage predation of pupae buried in groups of five and singly at different soil depths, together with the standard errors and the number of trials, is shown in Fig. 1.

Percentage recovery declined with increasing depth: predation of groups of pupae at $20 \mathrm{~mm}$ depth reached almost $100 \%$, fell to less than $50 \%$ at $80-120 \mathrm{~mm}$ and was no more than $8 \%$ at $160 \mathrm{~mm}$. Discovery of a food point where five pupae were buried resulted in all the prey at that point being located and eaten in nearly all cases.

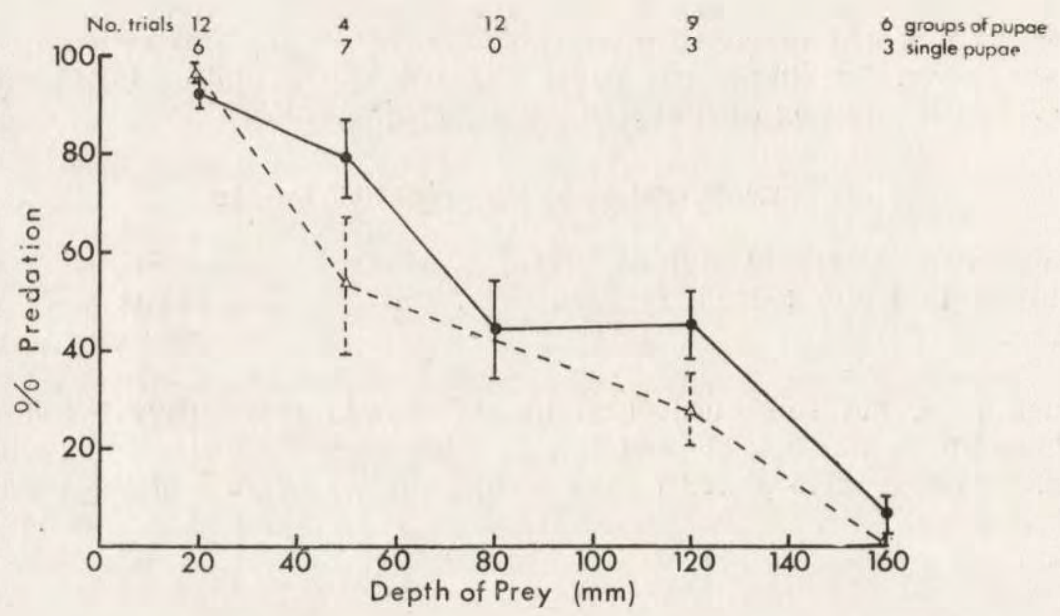

Fig. 1. Mean predation by captive $S$. araneus of pupae buried singly $(--\rightarrow$ and in groups of five $(\longrightarrow$ ) at different depths, with standard errors.

The recovery of single pupae showed a similar trend but tended to be lower than that of groups of pupae. At $20 \mathrm{~mm}$ depth predation approached $100 \%$ but by $120 \mathrm{~mm}$ it had declined to under $30 \%$. No single pupae were recovered by shrews at $160 \mathrm{~mm}$.

The results are complicated by the great individual variation which remained high regardless of the number of trials, and this makes comparisons on a statistical basis impracticable. Not only was there great inter-individual variation in overall foraging ability, but also intra-trial variation where the performance of individuals in the same trial repeated on several occasions differed.

\subsection{Predation at Different Prey Densities}

The mean percentage predation of single pupae buried at $50 \mathrm{~mm}$ in the soil at different densities is shown in Fig. 2. A trend of increasing 
predation with increasing density of prey is evident, despite the considerable individual variation. When density reached 20 pupae, recovery approached $100 \%$ and individual variation was low. Between densities of one and 10 inclusive the mean predation was only $50-67 \%$. and individual variation was high. Duplication of trials with a density of one pupa revealed a high degree of variation in the results, with shrews locating the single prey item on one occasion but not on another. A mean of $66.7 \%$ was obtained from all the trials conducted at this density, and this is plotted in Fig. 2.

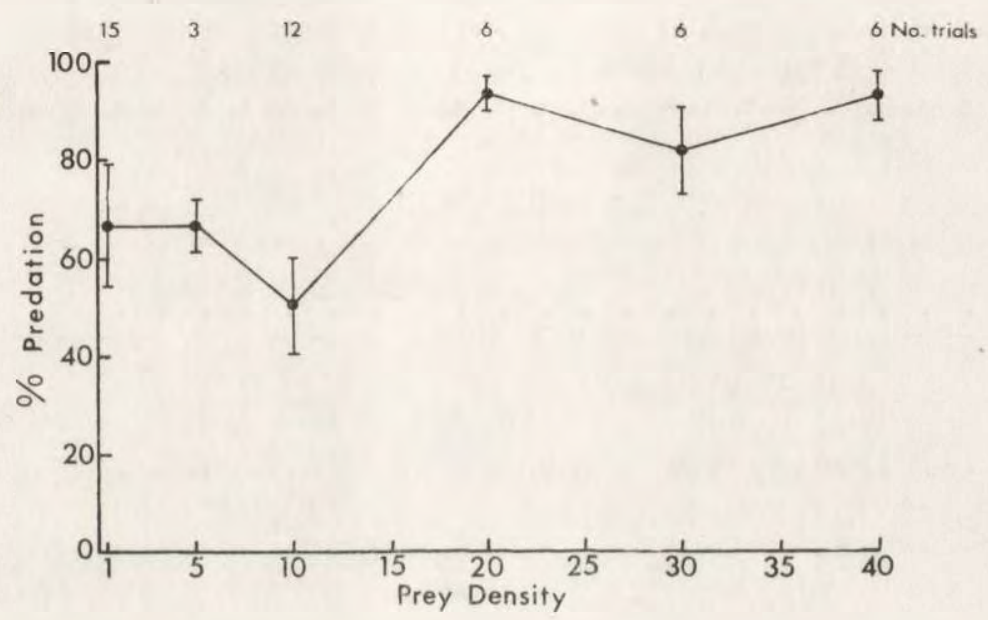

Fig. 2. Mean predation by captive $S$. araneus of pupae burried singly at $50 \mathrm{~mm}$. depth in different densities, with standard errors.

\subsection{Burrowing Activity}

Shrews exhibited little burrowing activity. During the foraging experiments they merely constructed surface runs amongst the leaf litter and up to three small burrows $30 \mathrm{~mm}$ deep.

When the foraging experiments were terminated, six shrews were maintained undisturbed in their enclosures for 2-4 months, after which the enclosures were thoroughly searched for burrows. Even after four months, burrowing was minimal, with runs and small holes: amongst the leaf litter and surface soil, and up to three small U-shaped burrows in each enclosure. These burrows were $30-120 \mathrm{~mm}$ deep and $90-200 \mathrm{~mm}$ long, and were usually constructed at the edges of the enclosure or beneath the nest-box. They were smooth with use but rarely contained nests. If disturbed from their regular nesting sites in 
the boxes provided, shrews often retreated into these burrows where they were completely hidden. Shrews always nested in the boxes provided, and if hay bedding was not included, a nest would be constructed from dried leaves augmented with small stones and lumps of soil carried into the box. Occasionally a shrew changed its nesting site to one of the U-shaped burrows, with an entrance hole at each end and a nest of leaves in the centre, but such burrows never exceeded $120 \mathrm{~mm}$ in depth.

Three shrews each constructed a small, shallow depression in the soil some way from the nest and less than $30 \mathrm{~mm}$ deep. Each was covered over with leaf litter and contained a large hoard of blowfily pupae accumulated after the foraging experiments had ended. During the foraging trials no food caches were found.

\section{DISCUSSION}

The results of this study indicate a considerable ability of S. araneus to locate hidden, inactive prey without the apparent use to tactile, auditory or visual stimuli, but whether such intense digging activity occurs in the wild is not known. Digging to any depth in the wild is severely restricted by the compaction of the soil and the vegetation cover, and the recovery of pupae by shrews in this study may have been facilitated by the comparatively low soil compaction and the lack of live vegetation cover. No correlation between the level of predation and weather conditions was found, but no trials were conducted in frost or snow when prey location is most likely to be hampered.

The precise method by which hidden prey is detected is still unknown, but there are indications of olfactory cues coupled with random searching. Holling $(1958,1959)$ reports that Sorex cinereus cinereus and Blarina brevicauda talpoides could detect European pine sawfly cocoons by the odour emanating from them and, as in the present study, he found a decrease in predation with increasing depth of prey. The larger concentration of odour emanating from groups of pupae could explain the greater ability of $S$. araneus to locate pupae in groups rather than pupae buried singly. Holling $(1955,1958,1959)$ also found that shrews could distinguish between parasitised and unparasitised sawfly cocoons, eating only the latter, and suggested that this was due to scent. However, observations of $S$. araneus in the present study showed that although they underwent intense digging activity, they were unable to locate all pupae buried singly or in groups until several hours had elapsed, even when prey were buried at a depth of 
only $20 \mathrm{~mm}$. It seems doubtful, then, that detection of hidden prey occurs wholly by olfactory means.

Without further evidence of the olfactory ability of shrews, the results of the present study could be attributed to a random searching technique employed by shrews. Shrews would be unlikely to locate pupae may thus be easier to find. That olfactory stimuli are not the searched, and groups of pupae occupying a greater area than single pupae may thus be easier to find. That olfactory stimuli are not the only means of prey location is further indicated by the results of three foraging trials using pupae coated with varnish in an attempt to prevent the odour emanating from the prey. Both varnished and unvarnished pupae buried in equal numbers at $50 \mathrm{~mm}$ depth were taken in equal proportions by shrews. Although the varnish may not prevent the odour emanating from the pupae completely it could be expected to reduce it or replace it with another, unfamiliar scent, but further work is required to test this.

The increasing predation with the increase in density of pupae also indicates random search, for the greater proximity of the prey and the larger area occupied by them would increase their chances of location. If detection occurs solely by scent it might be expected that, at a constant depth to which shrews had proved capable of foraging, all hidden pupae would be located. This would occur regardless of density, provided, as in the present study, the number of prey did not exceed the daily energy requirements of the shrew. Predation might even increase at higher densities if there is a tendency to hoard surplus food. Holling (1959), too, found increasing predation by shrews with increasing density of sawfly cocoons in the wild, but a maximum was reached which corresponded with the maximum daily consumption by captive shrews.

The interpretation of the results in the present study is complicated by the high degree of individual variation, an observation which was also noted by Crow croft (1955) when investigating the burrowing behaviour of shrews, and this may reflect differences in ability and inclination between individuals. The intense searching activity of shrews observed in the present study was also remarked upon by Southern (1954) and Crowcroft (1959) in foraging experiments on house mice (Mus musculus). C row cr of t (1959) found that house mice never took their entire day's supply from one food point but made use of all the food points provided. Pernetta (1977) found that shrews tended to re-investigate the same area once a prey item had been caught there, and this is confirmed in the present study where all the pupae buried in a group were taken. 
Despite such intense foraging activity, shrews did not construct extensive burrow systems. Even after four months spent undisturbed in outdoor enclosures, shrews merely constructed small U-shaped burrows within $90-120 \mathrm{~mm}$ of the ground surface. This contrasts with the burrowing activity of Apodemus sylvaticus (Linnaeus, 1758), one of which made a tunnel $0.24 \mathrm{~m}$ deep and $0.8 \mathrm{~m}$ long within a month. C rowcroft (1955) reports digging activity of $S$. araneus to be intense but he does not mention the length or depth of the burrows, or whether they were used for nesting. However, they could not have exceeded four inches, the depth of soil he provided for them.

Shrews are believed to use subterranean burrows and readily retreat into small holes and crevices when released from traps. This, coupled with their poor ability to create extensive burrows, indicates a use of tunnel systems constructed by more adept burrowers such as $A$. sylvaticus, but further studies are required to investigate this.

Acknowledgements: I wish to thank my supervisor, Dr. J. Griffith, and Prof. J. E. Webb, in whose department this work was carried out, for their help and support. I am indebted to Dr. J. Gurnell for much useful discussion and help in the preparation of this manuscript. This research was carried out during tenure of a postgraduate studentship (Mary Scharlieb Award) administered by the University of London, to whom I extend my thanks.

\section{REFERENCES}

1. Adams L. E., 1912: The duration of life of the common and lesser shrew with some notes on their habits. Mem. Proc. Manchr. Lit. Phil. Soc., 56: 1-10.

2. Churchfield J. S., 1979: Studies on the ecology and behaviour of British shrews. Ph. D. unpubl. thesis, Univ. of London.

3. Crowcroft W. P., 1955: Notes on the behaviour of shrews. Behaviour, 8: $63-80$.

4. Crowcroft P., 1959: Spatial distribution of feeding activity in the wild house-mouse (Mus musculus L.). Annals of Appl. Biol., 47 I: 150-155.

5. Hamilt on W. J., 1931: Habits of the short-tailed shrew Blarina brevicauda (Say). Ohio J. Sci., 31: 97-106.

6. Holling C. S., 1955: The selection by certain small mammals of dead, parasitised and healthy prepupae of the European sawfly, Neodiprion sertifer (Geoff.). Can. J. Zool., 33: 404-419.

7. Holling C. S., 1958: Sensory stimuli involved in the location and selection of sawfly cocoons by small mammals. Can. J. Zool., 36: 633-653.

8. Holling C. S., 1959: The components of predation as revealed by a study of the small mammal predation of European sawfly. Can. Ent., 41: 293-332.

9. Kisielewska K., 1963: Food composition and reproduction of Sorex araneus in the light of parasitological research. Acta theriol., 7: 127-153.

10. Mezhzherin V. A., 1958: On the feeding habits of Sorex araneus and Sorex minutus. Zool. Z., 37: 948-953.

11. Pernetta J. C., 1973: Field and laboratory experiments to determine the 
feeding ecology and behaviour of Sorex araneus and S. minutus. D. Phil unpubl. thesis, Univ. of Oxford.

12. Pernetta J. C., 1976: Diets of the shrews Sorex araneus L. and Sorex minutus L. in Wytham grassland. J. Anim. Ecol., 45: 899-913.

13. Pernetta J. C., 1977: Anatomical and behavioural specialisations of shrews in relation to their diet. Can. J. Zool., 55: 1442-1453.

14. R u d ge M. R., 1968: Food of the common shrew, Sorex araneus, in Britain. J. Anim. Ecol., 37: 565-581.

15. Southern H .N., ed., 1954: Control of rats and mice. Vol. 2: Rats. Clarendon Press: Oxford.

Accepted, May 15, 1980.

\section{Sara CHURCHFIELD}

\section{ZDOBYWANIE POKARMU POD ZIEMIA I KOPANIE NOR U RYJOWKI} AKSAMITNEJ

\section{Streszczenie}

Ryjówki trzymano w zagrodach $1,22 \times 0,80 \mathrm{~m}$, których dno stanowiła $30 \mathrm{~cm}$ warstwa gleby pokryta liśćmi. Od góry przykrycie stanowiła siatka. Badano ich zdolność do znajdywania poczwarek zakopanych na różnej głębokości w ziemi o różnym stopniu twardości (Ryc. 1,2). Zebrano dane o zdolności ryjówek do rycia. Omówiono metody lokalizowania ofiar przez ryjówki i wykorzystanie przez nie tuneli podziemnych. 